\title{
A Systematic Review of Zero-markup Policy for Essential Drugs Effect on Medical Treatment
}

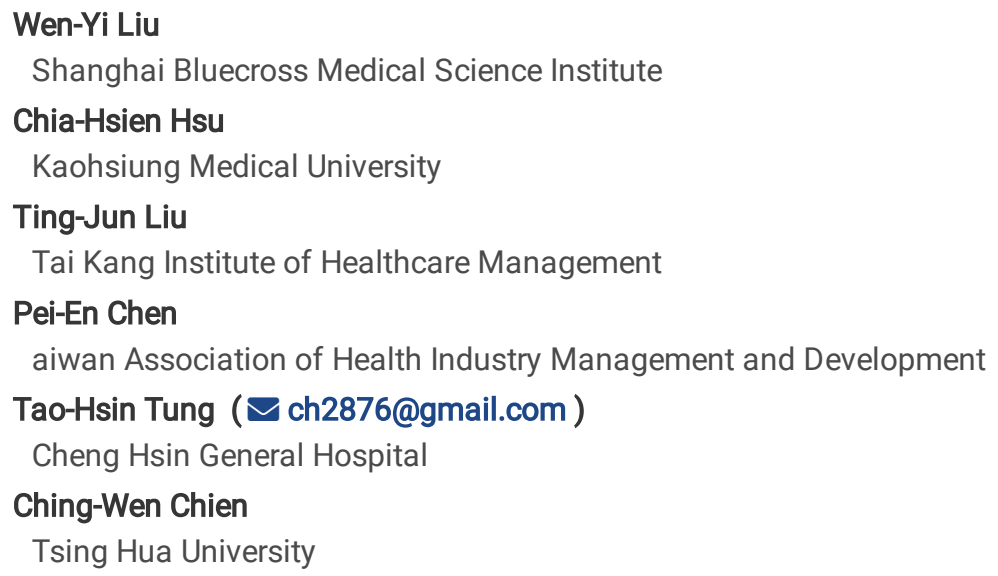




\section{Abstract}

Objective. This systematic review is conducted to synthesize recent empirical evidence of Zero-markup Policy for Essential Drugs Effect on Medical Treatment in China.

Methods. We searched the PubMed, Embase, Scopus, and Cumulative Index to Nursing and Allied Health Literature (CINAHL) for all related studies published from inception to 30 April 2019 without restriction on language. In addition, grey literatures were captured through other sources, such as OpenGrey and Open Access Theses and Dissertations (OATD), to avoid selection bias. Methodological quality were evaluated using the PRISMA statement the Newcastle Ottawa Scale Collaboration tool.

Results. Thirty-four full texts were initially searched, but only nine studies met our inclusion criteria. Most of studies indicated the significant reduction for both the total expense and drug expense per visit. Additionally, outpatient and inpatient services indicated increasing trends in annual patient-visits.

Conclusions. In conclusion, the available limited, relative low-quality evidence does not support the long-term association between zeromarkup policy for essential drugs and reduced medical expenditure. Further longitudinal studies that provide data for hospitals over a wider range of regions would make the economic effects more discursive.

\section{Background}

In 1954, Policy on Drug Markups (PoDM) announced by Chinese government granted medical institutions to raise pharmaceuticals price by maximum to $15 \%$ cap [1]. Since 1980s lacking enough fiscal subsidy and facing raised drug price, patients were struggling with health care [2]. To alleviate these challenges, Medical health reform was initiated by Chinese government and Zero-markup Policy for Essential Drugs (ZPED) was published in 2009. ZPED demonstrated that markup from pharmaceutical bills would no longer exist and $10 \%$ of original $15 \%$ markup under PoDM would be replaced by fiscal subsidy. The solution of rest payment would be deemed a ridiculous way that diagnosis costs would be raised to cover $80 \%$ of original markup. The rest was subject to medical institutions themselves [3].

Although ZPED was critical to limit rapid increasing drug price, it could not avoid financial burden of patients transferred gradually from drug price to other medical payment at last. For example, at the beginning (2009-2011) per visit patient medication expense was reduced, especially in rural area and county. Zhou et. al. also believed dependence on drug revenue to subsidize the deficit of hospitals could be controlled by ZPED [4]. From 2011 to 2015, ZPED was not longer a pilot program and gradually applied to all the county medical institutions in China. However, Yang et. al, found that medical expenditure was still increasing, although its rising trend was restrained [2]. This might be that medical institutions were entitled to raise other medical expenditure, such as diagnosis payment, nursing fees, surgery expense and treatment fees, under ZPED [2].

Most studies focus on long-term effects of ZPED on per visit expenditure, especially drug expense, but ignore the whole payment of one course of treatment. Therefore, this study utilize systematic review to explore the effect of ZPED on annual medical expense of per citizen and expenditure of one course of treatment.

\section{Methods}

\section{Data source and searches}

The literature search was conducted using PubMed, Embase, Scopus, and Cumulative Index to Nursing and Allied Health Literature (CINAHL) for all related studies published until 30 April 2019 without restriction on language. In addition, grey literatures were captured through other sources, such as OpenGrey and Open Access Theses and Dissertations (OATD), to avoid selection bias. A search strategy was developed for the aforementioned electronic databases, using key words as follows: ("pharmaceutical*" [Title/Abstract] OR "drug *" [Title/Abstract] OR “medicine*" [Title/Abstract]) AND (("zero" [Title/Abstract]) AND ("markup" [Title/Abstract] OR "mark-up" [Title/Abstract])). The reference lists of the screened related articles were manually examined to further identify additional similar studies (Table 1). In addition, no patients were involved in this study. We used data from published papers only. IRB approval was not required for the study.

\section{Study selection}

Two reviewers independently screened eligible studies that focused on the impacts of ZEPD on annual medical expense of per citizen and expenditure of one course of treatment. The disagreements resolved via discussion with a third author. These studies should be original articles instead of letters to the editor or conference abstracts. Also, the outcomes which these included studies investigated should be 
linked to financial indicators of healthcare institutions, for example, total expenditure per inpatient/outpatient visit, drug expenditure per inpatient/outpatient visit, number of inpatient/outpatient visits, and so forth.

\section{Data extraction and quality assessment of methodology}

Two reviewers independently abstracted the following characteristics of included studies based on a normalized data collection form: author, publication year, study design, area, hospital accreditation, outcomes, statistical methods, and conclusions. As for quality assessment, the Newcastle Ottawa Scale (NOS) [5], a recommended and validated tool for evaluating methodologic quality in nonrandomized studies, was used to assess the quality of the included studies independently by the same two reviewers. Regarding the quality ratings as shown in Table 2, each asterisk represents one point and the total NOS score is the sum of the points (a maximum of 9), which are assigned for selection (4 points), comparability (2 points), and outcome (3 points).

\section{Data synthesis and analysis}

There were four broad outcome variables: 1. Total expenses (inpatient/outpatient service); 2. Drug expenses (inpatient/outpatient service); 3. Number of patients' visit. Outcome variables were assessed at baseline and intervention point.

\section{Results}

\section{Characteristics of the included trials}

As illustrated in Fig. 1, our search identified 34 records after removing duplicates. We excluded 25 records that did not meet our inclusion criteria. Nine studies (included time series study, retrospective cohort study, and quasi-experimental study) were included in this systematic review [1-4, 6-10]. The characteristics of the included studies are summarized in Table 3. These studies were published between 2015 and 2019. All selected studies were from China. In addition, all nine of the studies were rated less than seven stars on the NOS scale and were considered of relative low quality. As shown in Table 3, various sets of outcomes were measured.

\section{Total expenses}

Based on the quasi-experimental design, the total expense per visit reduced by 3.12 USD and 65.6 USD for outpatient and inpatient services, respectively. The expense per visit was estimated $11 \%$ reduction for both outpatient and inpatient services [4]. A retrospective longitudinal study indicated that in absolute terms, there were increased annual patient-visits [6]. Yang et al (2017) indicated the statistically significant decreasing of monthly hospitalization expenditure [2]. Fu et al (2018) showed that a rise in expenditures for medical services and no changes in total health expenditures [8]. In addition, He et al (2018) showed the results that pharmaceutical reform could not reduce total health expenditure in long term [3]. There was a statistical significantly positive correlation between the rate of services compensation and the proportion of medical service revenue [1]. However, Mao et al (2019) concluded that no significant change of the average medical expenditure per prescription was observed [10].

\section{Drug expenses}

Zhou, et al (2015) showed that the drug expense per visit dropped by 4.47 USD and 45.75 USD for outpatient and inpatient services, respectively. They also found that the proportion of drug expense out of total expense per visit dropped by $11.73 \%$ and $3.92 \%$ in outpatient and inpatient visits, respectively [4]. Yin et al (2018) indicated that ZPED could improve rational use of antibiotic were related to the reduction of antibiotic consumption [9]. Fu et al (2018) found the policy change led to a decreased in drug expenditures [8]. He et al (2018) showed the results that pharmaceutical reform only could short term reduced drug expenditure [3]. Mao et al (2019) also found that the average number of medicines per prescription, use of antibiotics, intramuscular injections and intravenous injections decreased while the use of hormones increased [10].

\section{Number of patients' visits}

Tian et al (2016) found that ratios of medicine-to-healthcare-charges decreased in outpatient and inpatient services. Both outpatient and inpatient services showed increasing trends in annual patient-visits [6]. Wei et al (2017) concluded that ZPED may be correlated to reductions in outpatient antibiotic prescribing and intravenous infusions [7].

\section{Others}

The inpatient physician work-days increased and inpatient mortality-rate reduced, physician work-days decreased and physician-workload and inflation-adjusted per-visit healthcare charges increased in outpatient service [6]. 


\section{Discussion \\ Clinical implications}

From the best of our knowledge, this is the first systematic review to explore the ZPED on medical treatment in China. According to the selected studies, we found the significant reduction for both the total expense and drug expense per visit. In addition, outpatient and inpatient services indicated increasing trends in annual patient-visits. In China, economic incentive and profits from prescribing medicines was the most frequently mentioned potential influent factor due to previous systematic review showed that irrational use of medicines was severe [11]. However, the improvement on the rational use of medicine still has many unexpected challenge. ZPED is a national level's medicines, then lower level governments extend the list based on the demands. Medicines without lists are not allowed in prescriptions [7]. The main consequence for the medical policy is that hospitals are not only never sufficiently compensated, but also face many financial difficulties based on the complex medical environment [12].

It implied that the structure of inpatient and outpatient utilization may be changed because ZPED decreased healthcare costs for patients. The patients' medical decision making on whether to utilize inpatient services are determined by factors other than outpatient price [13]. Evidenced findings from behavioral economics studies showed that subjects usually make decisions not only based on absolute, but also on relative changes in price $[4,14]$. This appearance is at the central of relative thinking theory, which indicates that people are influenced more by relative changes than absolute changes in a given base line [14].

From the policy viewpoint, these findings of selected studies concerns about the health care cost containment policy that changes prices for drugs and clinical services. To change prices for drugs and medical services is a widely used policy instrument in western countries [8]. The price regulations alone would not yield the satisfactory cost reduction due to health providers would circumvent the regulations by information advantage. It is inevitable that China also faced great pressures to health care. To increase the provisions of other medical services with higher price-cost margins may compensate for the revenue loss in Chinese public hospitals [8]. In addition, Diagnosis-Related Group (DRG) may be considered to address the inappropriate utilization of drugs and services and to reduce healthcare expenditure. The experience in Beijing had indicated that the introduction of DRG payment system decreased expenditures and out-of-pocket spending per admission [15].

\section{Clinical practice}

This systemic review found that despite there is some heterogeneity in total expense, there is significant improvement of drug expenses and number of patients' visits. Based on the results, medical teams should develop the customized protocol to control or reduce medical expenses from the heart of ZPED because the increase or decrease of the medicine or healthcare charges is mainly dependently on the hospital levels [16]. Such as both outpatient and inpatient charges were decreased in township health centers but not of country levels or above [6]. For better expenditures improvement, the monitor system should long-term evaluation with progressive and alternative strategies.

\section{Methodological considerations}

Several limitations should be considered when interpreting the results of this study. Firstly, the small number of included studies limits the strength of the conclusions that were drawn. Secondly, the selected studies are of variable methodological quality, which introduced the risk of bias (Table 2). Thirdly, we were unable to conduct meta-analysis analyses based on selected studies because the included studies did not provide consistent information. Finally, the results might not be generalizable to other hospitals, as the studies we reviewed were conducted in just some regions in China. The external validity also should be further discussed.

\section{Conclusion}

Although the positive effects were demonstrated of ZPED, the available limited and relative low-quality evidence does not support the longterm association between zero-markup policy for essential drugs and reduced medical expenditure. Further longitudinal studies that provide data for hospitals over a wider range of regions in China would make the economic effects more discursive.

\section{Abbreviations}

Zero-markup Policy for Essential Drugs(ZPED)

Policy on Drug Markups (PoDM)

Cumulative Index to Nursing and Allied Health Literature (CINAHL)

Page $4 / 12$ 
Open Access Theses and Dissertations (OATD)

Newcastle Ottawa Scale (NOS)

Diagnosis-Related Group (DRG)

\section{Declarations}

\section{Ethics approval and consent to participate}

Not applicable

\section{Consent to publish}

Not applicable

\section{Availability of data and materials}

All data underlying the findings are within the paper.

\section{Competing interests}

The authors have no proprietary interest in any aspect of this study.

\section{Funding}

There was no additional financial support from public or private sources.

\section{Authors' Contributions}

Liu WY, Hsu CH, Liu TJ, Chen PE, Tung TH, and Chien CW conducted the study and drafted the manuscript. Liu WY, Hsu CH, Liu TJ participated in the design of the study and performed statistical analyses. Chen PE, Tung TH, and Chien CW conceived the study, and participated in its design and coordination. All of the authors read and approved the final manuscript.

\section{Acknowledgements}

Not applicable

\section{References}

[1]Tang W, Xie J, Lu Y, et al. Effects on the medical revenue of comprehensive pricing reform in Chinese urban public hospitals after removing drug markups: case of Nanjing. J Med Econ 2018;21:326-339.

[2]Yang C, Shen Q, Cai W, et al. Impact of the zero-markup drug policy on hospitalisation expenditure in western rural China: an interrupted time series analysis. Trop Med Int Health 2017;22:180-186.

[3] He Y, Dou G, Huang Q, et al. Does the leading pharmaceutical reform in China really solve the issue of overly expensive healthcare services? Evidence from an empirical study. PLoS One 2018 16;13:e0190320.

[4]Zhou Z, Su Y, Campbell B, et al. The financial impact of the 'zero-markup policy for essential drugs' on patients in county hospitals in western rural China. PLoS One 2015;10:e0121630.

[5]Lo CK, Mertz D, Loeb M. Newcastle-Ottawa Scale: comparing reviewers' to authors' assessments. BMC Med Res Methodol 2014;14:45.

[6]Tian W, Yuan J, Yang D, et al. Descriptive Analysis on the Impacts of Universal Zero-Markup Drug Policy on a Chinese Urban Tertiary Hospital. PLoS One 2016;11:e0162795.

[7]Wei X, Yin J, Walley JD, et al. Impact of China's essential medicines scheme and zero-mark-up policy on antibiotic prescriptions in county hospitals: a mixed methods study. Trop Med Int Health 2017;22:1166-1174. 
[8]Fu H, Li L, Yip W. Intended and unintended impacts of price changes for drugs and medical services: Evidence from China. Soc Sci Med 2018;211:114-122.

[9] Yin J, Li Q, Sun Q. Antibiotic consumption in Shandong Province, China: an analysis of provincial pharmaceutical centralized bidding procurement data at public healthcare institutions, 2012-16. J Antimicrob Chemother 2018;73:814-820

[10]Mao W, Huang Y, Chen W. An analysis on rational use and affordability of medicine after the implementation of National Essential Medicines Policy and Zero Mark-up Policy in Hangzhou, China. PLoS One 2019;14: e0213638.

[11]Mao W, Vu H, Xie Z, et al. Systematic Review on Irrational Use of Medicines in China and Vietnam. PLoS ONE 2015:10:e0117710.

[12]Mao W, Chen W. The Zero Mark-up Policy for essential medicines at primary level facilities, China case study. In: Xu K (ed). Improving Health System Efficiency, Health Systems Governance \& Financing. World Health Organization: Geneva, 2015.

[13]Zhou Z, Su Y, Gao J, et al. New Estimates of Elasticity of Demand for Healthcare in Rural China. Health Policy 2011;103:255-265.

[14]Azar O. Relative thinking theory. The Journal of Socio-Economics 2007;36:1-14.

[15]Jian W, Lu M, Chan KY, et al. Payment reform pilot in Beijing hospitals reduced expenditures and out-of-pocket payments per admission. Health Aff 2015;34:1745-1754.

[16]Wang J, Zhen J, Fan W, et al. Investigation and analysis of the effects of national essential drug system on medical expenses in different levels of medical Institutions. Chin Pharm 2013;23:2982-2984.

\section{Tables}

Table 1. Search strategy in PubMed up until April 2019 (similar search run in other databases)

1. "pharmaceutical*” [Title/Abstract]

1. "drug*" [Title/Abstract]

1. "medicine*" [Title/Abstract]

1. 1 OR 2 OR 3

1. "zero" [Title/Abstract]

1. "markup" [Title/Abstract]

1. "mark-up" [Title/Abstract]

1. 6 OR 7

1. 5 AND 8

1. 4 AND 9 


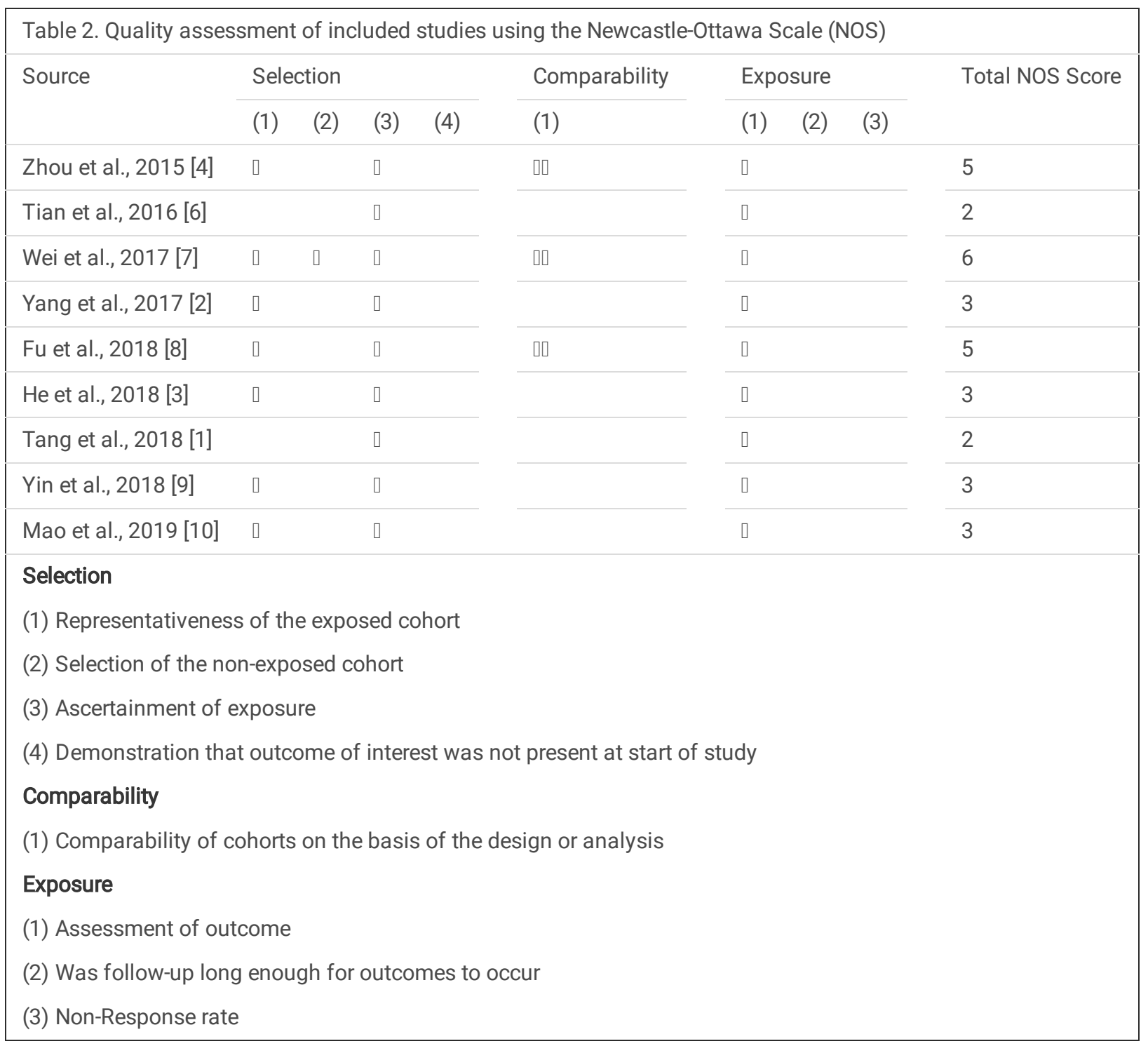




\begin{tabular}{|c|c|c|c|c|c|c|c|}
\hline Author & $\begin{array}{l}\text { Publication } \\
\text { year }\end{array}$ & Study design & Area & $\begin{array}{l}\text { Hospital } \\
\text { accreditation }\end{array}$ & Outcomes & $\begin{array}{l}\text { Statistical } \\
\text { methods }\end{array}$ & Conclusions \\
\hline $\begin{array}{l}\text { Zhou } \\
\text { et } \\
\text { al. [4] }\end{array}$ & 2015 & $\begin{array}{l}\text { Quasi- } \\
\text { experimental } \\
\text { study }\end{array}$ & $\begin{array}{l}\text { Ningshan } \\
\text { County } \\
\text { and } \\
\text { Zhenping } \\
\text { County, } \\
\text { Shaanxi } \\
\text { Province }\end{array}$ & Secondary & $\begin{array}{l}\text { - Total expense per } \\
\text { visit } \\
\text { (inpatient/outpatient } \\
\text { service) } \\
\text { - Drug expense per } \\
\text { visit } \\
\text { (inpatient/outpatient } \\
\text { service) }\end{array}$ & $\begin{array}{l}\text { - Hospital- } \\
\text { data } \\
\text { difference- } \\
\text { in- } \\
\text { differences } \\
\text { - Individual- } \\
\text { data } \\
\text { regressions }\end{array}$ & $\begin{array}{l}\text { The } \\
\text { absolute } \\
\text { monetary } \\
\text { reduction } \\
\text { of the per- } \\
\text { visit } \\
\text { inpatient } \\
\text { expense is } \\
20 \text { times } \\
\text { of that in } \\
\text { outpatient } \\
\text { care } \\
\text { The } \\
\text { relative } \\
\text { reductions } \\
\text { are the } \\
\text { same for } \\
\text { outpatient } \\
\text { and } \\
\text { inpatient } \\
\text { visits } \\
\text { The } \\
\text { incentive } \\
\text { to utilize } \\
\text { outpatient } \\
\text { or } \\
\text { inpatient } \\
\text { care } \\
\text { attributed } \\
\text { to Zero- } \\
\text { markup } \\
\text { Policy for } \\
\text { Essential } \\
\text { Drugs is } \\
\text { equivalent, } \\
\text { regardless } \\
\text { of the price } \\
\text { difference } \\
\text { in absolute } \\
\text { terms } \\
\text { ond }\end{array}$ \\
\hline $\begin{array}{l}\text { Tian } \\
\text { et } \\
\text { al. [6] }\end{array}$ & 2016 & $\begin{array}{l}\text { Descriptive } \\
\text { study } \\
\text { (retrospective } \\
\text { longitudinal } \\
\text { study) }\end{array}$ & Beijing & Tertiary & $\begin{array}{l}\text { - Annual patient-visits } \\
\text { - Ratios of medicine- } \\
\text { to-healthcare- } \\
\text { charges (RMOH) } \\
\text { - Physician work-days } \\
\text { (inpatient/outpatient } \\
\text { service) } \\
\text { - Physician-workload } \\
\text { (inpatient/outpatient } \\
\text { service) } \\
\text { - Inflation-adjusted } \\
\text { per-visit healthcare } \\
\text { charges } \\
\text { (inpatient/outpatient } \\
\text { service) } \\
\text { - Mortality-rate } \\
\text { (inpatient/outpatient } \\
\text { service) }\end{array}$ & $\begin{array}{l}\text { - Rank-sum } \\
\text { tests } \\
\text { - Join-point } \\
\text { regression } \\
\text { analyses }\end{array}$ & $\begin{array}{l}\text { Implementation } \\
\text { of Universal } \\
\text { Zero-Markup } \\
\text { Drug Policy: } \\
\text { - Increase } \\
\text { annual } \\
\text { patient- } \\
\text { visits } \\
\text { - Reduce } \\
\text { RMOH } \\
\text { - Have } \\
\text { different } \\
\text { impacts on } \\
\text { outpatient } \\
\text { and } \\
\text { inpatient } \\
\text { services }\end{array}$ \\
\hline $\begin{array}{l}\text { Wei et } \\
\text { al. [7] }\end{array}$ & 2017 & $\begin{array}{l}\text { Natural } \\
\text { experiment }\end{array}$ & Guangxi & N/A & $\begin{array}{l}\text { - Antibiotic } \\
\text { prescribing rate } \\
\text { (outpatients with a } \\
\text { primary diagnosis of } \\
\text { upper respiratory } \\
\text { tract infection) }\end{array}$ & $\begin{array}{l}\text { Difference- } \\
\text { in- } \\
\text { difference } \\
\text { analyses }\end{array}$ & $\begin{array}{l}\text { The national } \\
\text { essential } \\
\text { medicines } \\
\text { scheme and } \\
\text { zero-mark-up } \\
\text { policy may be } \\
\text { associated with } \\
\text { reductions in } \\
\text { outpatient } \\
\text { antibiotic }\end{array}$ \\
\hline
\end{tabular}




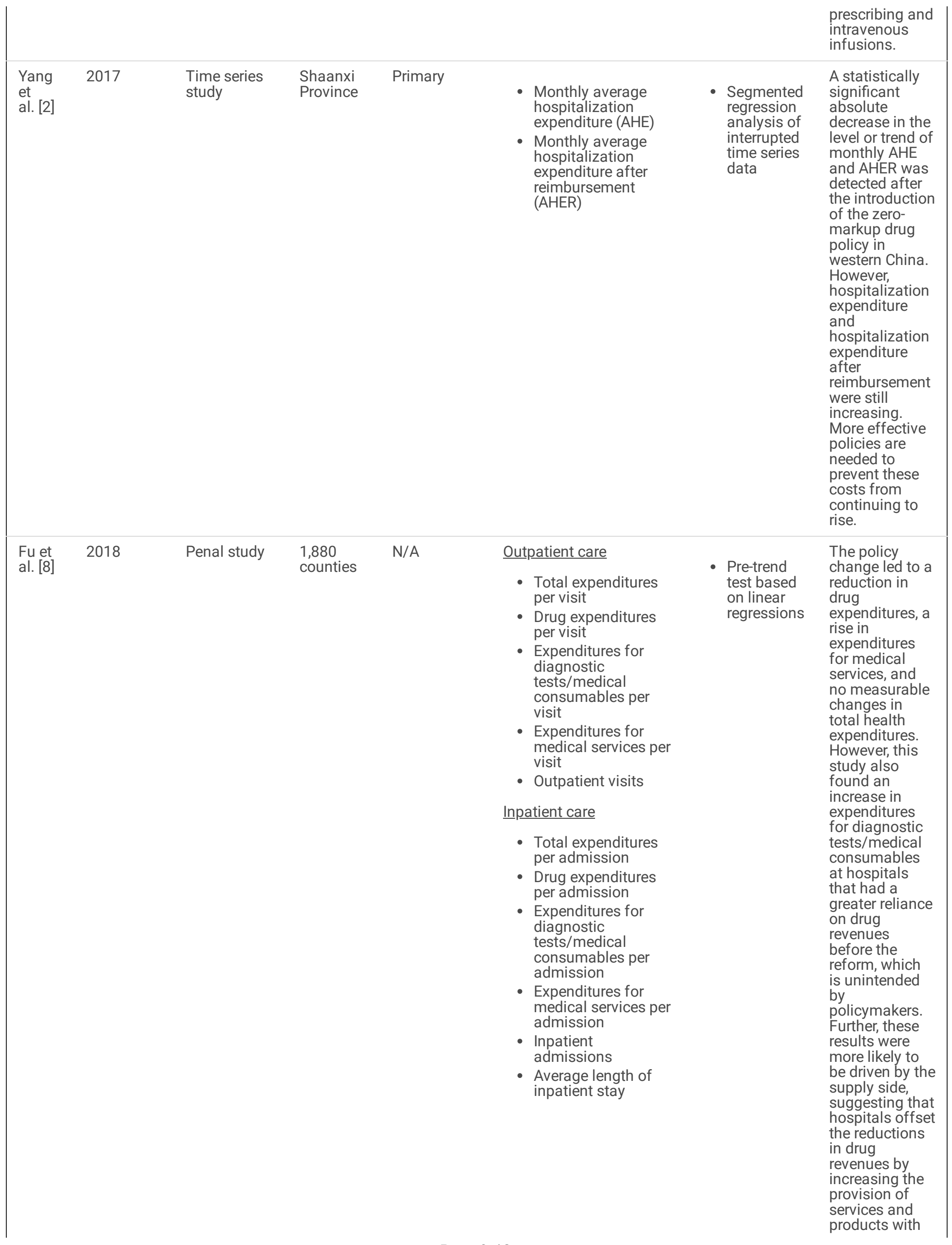




\begin{tabular}{|c|c|c|c|c|c|c|c|}
\hline & & & & & & & $\begin{array}{l}\text { higher price- } \\
\text { cost margins. }\end{array}$ \\
\hline $\begin{array}{l}\text { He et } \\
\text { al. [3] }\end{array}$ & 2018 & $\begin{array}{l}\text { Time series } \\
\text { study }\end{array}$ & $\begin{array}{l}\text { Sanming } \\
\text { City, } \\
\text { Fujian } \\
\text { Province }\end{array}$ & $\begin{array}{l}\text { Secondary } \\
(n=4) \text { and } \\
\text { Tertiary } \\
(n=21)\end{array}$ & $\begin{array}{l}\text { - Outpatient drug } \\
\text { expenditure } \\
\text { - } \text { Outpatient total } \\
\text { health expenditure } \\
\text { - Inpatient drug } \\
\text { expenditure } \\
\text { - Inpatient total health } \\
\text { expenditure }\end{array}$ & $\begin{array}{l}\text { - Interrupted } \\
\text { time series } \\
\text { analysis } \\
\text { with three } \\
\text { segments } \\
\text { divided by } \\
\text { two } \\
\text { intervention } \\
\text { points }\end{array}$ & $\begin{array}{l}\text { Although the } \\
\text { pharmaceutical } \\
\text { reform could } \\
\text { control or } \\
\text { reduced drug } \\
\text { expenditure } \\
\text { and total health } \\
\text { expenditure in } \\
\text { short term, } \\
\text { expenditures } \\
\text { gradually } \\
\text { resumed } \\
\text { growing again } \\
\text { and reached or } \\
\text { even exceeded } \\
\text { their baseline } \\
\text { levels of pre- } \\
\text { reform period, } \\
\text { indicating the } \\
\text { effect became } \\
\text { weakened or } \\
\text { even faded out } \\
\text { in long term. }\end{array}$ \\
\hline $\begin{array}{l}\text { Tang } \\
\text { et } \\
\text { al. [1] }\end{array}$ & 2018 & N/A & $\begin{array}{l}\text { Nanjing } \\
\text { City, } \\
\text { Jiangsu } \\
\text { Province }\end{array}$ & $\begin{array}{l}\text { Secondary } \\
\text { and Tertiary }\end{array}$ & $\begin{array}{l}\text { - The markup ratio of } \\
\text { drug sales } \\
\text { - The growth rate of } \\
\text { medical service } \\
\text { revenue }\end{array}$ & $\begin{array}{l}\text { - Simple } \\
\text { linear } \\
\text { interrupted } \\
\text { time series } \\
\text { regressions }\end{array}$ & $\begin{array}{l}\text { Nanjing's } \\
\text { pricing and } \\
\text { compensation } \\
\text { reform has } \\
\text { basically } \\
\text { achieved the } \\
\text { policy targets } \\
\text { of eliminating } \\
\text { the drug } \\
\text { markups, } \\
\text { promoting the } \\
\text { growth of } \\
\text { medical } \\
\text { services } \\
\text { revenue, and } \\
\text { adjusting the } \\
\text { structure of } \\
\text { medical } \\
\text { revenue. } \\
\text { However, the } \\
\text { growth rate of } \\
\text { service revenue } \\
\text { of hospitals } \\
\text { varied } \\
\text { significantly } \\
\text { from one } \\
\text { another. }\end{array}$ \\
\hline $\begin{array}{l}\text { Yin et } \\
\text { al. [9] }\end{array}$ & 2018 & $\begin{array}{l}\text { Time series } \\
\text { study }\end{array}$ & $\begin{array}{l}\text { Shandong } \\
\text { Province }\end{array}$ & $\begin{array}{l}\text { Secondary } \\
\text { tertiary, and } \\
\text { urban/rural } \\
\text { primary } \\
\text { healthcare } \\
\text { centers } \\
\text { (PHCs) }\end{array}$ & $\begin{array}{l}\text { - Total annual } \\
\text { antibiotic } \\
\text { expenditure } \\
\text { - Antibiotic } \\
\text { expenditure per } \\
\text { person per year }\end{array}$ & $\begin{array}{l}\text { Descriptive } \\
\text { statistics }\end{array}$ & $\begin{array}{l}\text { The overall } \\
\text { antibiotic } \\
\text { expenditure } \\
\text { increased over } \\
\text { time in } \\
\text { Shandong, } \\
\text { China. } \\
\text { However, the } \\
\text { increase rate of } \\
\text { expenditure } \\
\text { began to } \\
\text { decline in 2016, } \\
\text { possibly related } \\
\text { to the } \\
\text { implementation } \\
\text { of antibiotic } \\
\text { stewardship } \\
\text { initiatives. }\end{array}$ \\
\hline $\begin{array}{l}\text { Mao } \\
\text { et } \\
\text { al. [10] }\end{array}$ & 2019 & Penal study & $\begin{array}{l}\text { Hangzhou } \\
\text { City, } \\
\text { Zhejiang } \\
\text { Province }\end{array}$ & $\begin{array}{l}\text { Primary } \\
(n=6), \\
\text { secondary } \\
(n=2), \text { and } \\
\text { tertiary }(n=9)\end{array}$ & $\begin{array}{l}\text { - Average number of } \\
\text { medicines } \\
\text { - Average number of } \\
\text { antibiotics }\end{array}$ & $\begin{array}{l}\text { - T test } \\
\text { - Pearson } \\
\text { Chi-square } \\
\text { test or }\end{array}$ & $\begin{array}{l}\text { The average } \\
\text { number of } \\
\text { medicines per } \\
\text { prescription, } \\
\text { use of } \\
\text { antibiotics, }\end{array}$ \\
\hline
\end{tabular}


- Average expenditure per prescription
Fisher exact test intramuscular (IM) injections and

intravenous

(IV) injections

decreased

while the use of hormones

increased. No

significant

change of the

average

medicine

expenditure per

prescription

was observed.

The problems

of poly-

pharmacy,

overuse of

antibiotics,

intramuscular

(IM) injections

and

intravenous

(IV) injections

and hormones

still existed,

however

mitigated after

the

implementation

of The National

Essential

Medicine Policy

and the Zero

Mark-up Policy.

\section{Figures}




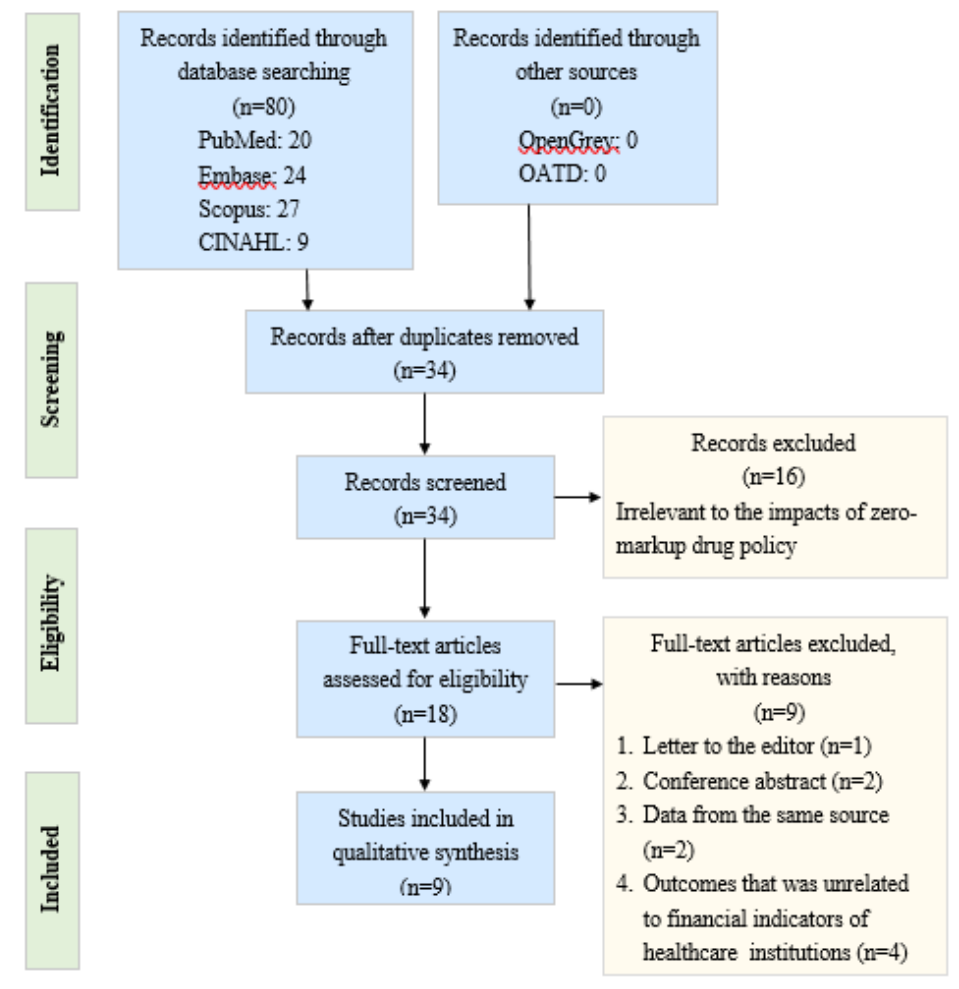

Figure 1 PRISMA (Preferred Reporting Items for Systematic Reviews and Meta-Analyses) flow

diagram.

(CINAHL: Cumulative Index to Nursing and Allied Health Literature;

OATD: Open Access Theses and Dissertations)

Figure 1

PRISMA (Preferred Reporting Items for Systematic Reviews and Meta-Analyses) flow diagram. (CINAHL: Cumulative Index to Nursing and Allied Health Literature; OATD: Open Access Theses and Dissertations)

\section{Supplementary Files}

This is a list of supplementary files associated with this preprint. Click to download.

- PRISMAChecklist2020.01.17.doc 